\title{
Factors Affecting Intention to Purchase Voluntary Pension Insurance in Vietnam
}

\author{
Duc Hieu Ninh*, Hoang Chau Giang Dang, Huyen Trang Ngo, Lam Phuong Bui, Thao Linh Le \\ School of Advanced Educational Programs, National Economics University, 207 Giai Phong Road, Vietnam
}

\begin{abstract}
:
The research was carried out with the aim to identify factors affecting the intention to purchase voluntary pension insurance in Vietnam. With data collected from 334 subjects across the country, mainly in Hanoi, the results showed that attitude towards risk, subjective norms, percieved behavioral control, past experiences and corporate branding have positive influences on the central factor, which is intent. After quantitative analysis, the study proposes recommendations for businesses to improve their services as well as methods of distribution to meet the needs of potential customers to save in pension funds. Additionally, the study will provide the basis for regulators to come up with measures to promote the retirement insurance market and at the same time, raise public awareness about social security.
\end{abstract}

Keywords: voluntary pension insurances, pension funds, puchase intention, TPB, annuity.

DOI: $10.7176 / \mathrm{EJBM} / 13-10-06$

Publication date:May $31^{\text {st }} 2021$

\section{Introduction}

Voluntary pension insurance or private pension plan is a type of periodical insurance contract between an insurance company and an individual or an organization with the purpose to ensure income after retirement or in the case of loss the ability to work. The emergence of private pension plan is inevitable since the majority of labors today thrives for financial autonomy when they reach retirement age. Instead of relying on relatives or expecting financial support from the State, people want to take a more proactive approach towards planning for retirement. In addition, the pressure of population aging on the social security system plus the current limitations of social insurance further consolidate the role of private pension plans.

The biggest benefit that comes from voluntary pension insurance is the guarantee of income for workers after retirement. The demand for retirement income is especially important for those unofficial workers who are known to have unstable jobs, lack labour contracts or work on verbal contracts to earn low income. With addtional source of income, the elderly can be self-controlled and secured to live a peaceful and comfortable life. In addition, voluntary pension insurance often comes with guaranteed health benefits, which is a top concern at old ages. It can be seen that the number of people paying social insurance and compulsory retirement insurance is still modest compared to the total number of workers in our country. The development of voluntary pension insurance aims to broaden the choice for workers, increase the supply of pension funds and promote the importance of saving for retirement. With the funding support from private sectors, Vietnamese government focuses on battling the challenges of aging population posed for the social security system. Viet Nam is at high risk of facing the unwanted outcomes due to population aging, provided the proportion of people aged 60 and over expected to double by 2050 , according to UN projections. With our country's current budget, the payment of pension for wokers is becoming increasingly difficult and there is a call for voluntary pension insurance funds to help alleviate this pressure.

Based on current situation in pension policies, the research team decided to select research topic on factors affecting the decision to buy voluntary pension insurance of people in Vietnam to analyze the demand for this new type of retirement scheme and propose solutions to increase public recognition as well as the urge to save in pension funds. In addition, the research team hopes that the relationship between factors affecting people's need to buy voluntary pension insurance will help insurance companies comes up with solutions to diversify products and takes advantage of the support from social security policies in our country.

\section{Literature Review}

\subsection{Theories on behavioral intentions, and behaviours of consumers}

The theory of Reasoned Action (TRA): The theory of reasonable action was first developed in 1967 by Martin Fishbein. TRA was formed with the aim of explaining an individual's voluntary behavior by considering the potential motive to perform such behavior. In other words, this theory proposes that individuals have different facilities and motivations in their decision-making process with a belief that the implementation of behavior will lead to a specific result. The TRA doctrine has also shown that a person's intention to perform a behavior is likely to predict whether or not they would actually perform it. The stronger the intention will lead to increased efforts to carry out the behavior and increase the likelihood that the behavior is carried out. Based on the theory of reasonable action, the element of intention will be influenced by attitudes to behavior and subjective norms related to behavior. 
The Theory of Planned Behavior (TPB): Planned Behavior Theory developed by Icek Ajzen in 1991 is based on reasonable action theory (Fishbein and Ajzen, 1980). The TPB model is considered more optimal than the TRA model in predicting and explaining consumer behavior due to its ability to account for involuntarily behaviors. Similar to the TRA model, the central factor is identified as the intention to perform the behavior, influenced by attitudes to behavior, subjective norms of behavior and one new factor is the perceived behavioral control.

Experiental Marketing Theory (SEMs): Schmitt first mentioned the term "Experiental Marketing" in 1999. This is considered a newer, more modern form of marketing than traditional methods. This new method still sees consumers as reasonable beings, but added with one more factor which is emotional. Instead of just buying based on the process of matching product's usage to benefits it offers, under Schmitt's marketing concept, people now have the tendency to go for products that bring them satisfied experiences. Schmitt's SEMs (Strategic Experiental Module) model consists of 5 factors: Sense, Feel, Think, Act, and Relate. Under the Experience Marketing theory, consumers will be more likely to buy a product if they have had a positive experience with it. For that reason, many studies have also applied the SEMs model to the study of purchasing intention and proved that this model is of research significance (Chao Chien et al., 2012; Khan and Rahman, 2015).

Hierarchy of Effects Theory: An impact hierarchy theory model was developed in 1961 by Lavidge and Steiner to measure the effectiveness of an advertising strategy on consumer purchasing decisions. The model holds that consumers acknowledge, process and use marketing informations in three stages: thinking-cognative phrases, feeling-affective phrase and doing-cognative phrase. These three stages also reflect the level of consumer brand awareness under the influence of advertising campaigns. At the initial stage, customers need to be introduced to the company's products and brands. Next, businesses will try to build trust, attract positive customer feelings about products and brands. And finally firms would rather hope that the promotion strategy is attractive enough to make consumers arrive at decisions to buy products. The theory of Lavidge and Steiner (1961) forms the basis for considering the impact of brand awareness on purchasing intention.

\subsection{Empirical researches on intention to purchase voluntary pension insurance}

In Western countries, saving is considered as one of the top concerns. In today's society, when issues such as population explosion, aging population, economic crisis, epidemic ... are still going on, saving is a necessary form of protection. The lifespan of the population has increased but the growth of pension funds is not enough to serve the elderly population, accompanied by economic crises: stock prices plummeted, bank interest rates fell,... Spain has created a strong incentive to save in the community (Letamendia \& Silva, 2015). The forms and purposes of saving vary in the US, however, young people generally tend to save and accumulate their weath. In particular, due to the fact that young people have more financial knowledge and prone to participate in venture capital forms, accept more debts and risks, they create conditions for generating savings to hedge against investment losses (Outcault, 2012). Lusardi and Tufano (2009) support the above view that those with more financial knowledge tend to spend more economically and have less debt. Besides, Maison et al. (2019), after doing research in Poland, concluded that when the financial situation or income is positively related to the demand for saving.

In Asia, research by Hong et al. (2002) also found that Korean people tend to accumulate wealth as a form of savings, especially after turning 40. In China, the imbalance in the sex ratio is believed to have a positive effect on household savings. Specifically, families with sons were observed to accumulate and save more (Zhang and Wei, 2011).

Awareness about owning annuities and saving for retirement age is increasingly focused. In the study of demographic factors influential in the intention to save voluntary retirement funds in Malaysia, Radduan Yuso et al. (2018) suggested that those who are considered seasoned savers with lots of past experience in saving and have the adequate money and time resources will tend to save higher for retirement age. Also in Malaysia, in the study of Hassan et el. (2016), the results showed that people aged 40 and over paid greater attention to pension issues. At the same time, the factors of education and psychology also positively affect the attitude towards retirement planning. The higher the level of education, the more interested they are in pension savings. The level of individual interest in making a retirement plan in the long run holds a close relationship with a business's ability to provide retirement insurance. In particular, the more people care about retirement-age financial matters, the more they interest in the retirement funds provided by the business and the higher the likelihood of them joining those funds.

Besides demographic factors, many studies applied models and theories surounding behavioral intention. Yusof et al. (2018) applied the Decomposed Theory of Planned Behaviour (DTPB) model to the study of the intention to join voluntary pension funds and concluded that the perceived behavioral control had the strongest impact. Besides, attitude also has a great influence on the intention to participate. According to Yusof et al. (2018), a person will start depositing in voluntary retirement funds if they can estimate the economic benefits and consider whether the schemes would suit their lifestyle or not. In addition, according to Amin (2012), the attitude has a much greater effect on purchase intention of risk-takers.

In the study of Paola Bongin et al. (2018) the subjective norms is the forecasting factor that contributes the most to the investing intention. That means students who live in an environment where their loved ones talk about 
pensions and consider saving in retirement as important will be more willing to save for their future. The next influential factor is knowledge about pension insurance. The results of the study showed that the sooner a person acquired knowledge about principles of insurance, the more likely young people would participate in retirement planning schemes. Numerous studies have also shown a positive link between financial knowledge and the intention to buy insurance (Mahdzan and Victorian, 2013; Zakaria et al., 2016; Jahan and Sabbir, 2018).

Sri Lanka is facing the reality that a large number of customers stop paying pension insurance halfway through. Researcher Heenkenda (2016) did an investigation to find out what factors influenced that decision. Ignorance of the benefits of private pension plans and marketing failures led to the decision to stop depositing into insurance companies of the majority of people.

In Vietnam, the number of studies on factors affecting insurance demand has increased significantly in recent years, showing the attraction and exploitation potential of this field, especially in life insurance sector. However, when going specifically into a branch of life insurance, which is voluntary pension insurance or annuity insurance, the number of research papers is limited. Studies on the intention to purchase life insurance show that demographic factors such as gender, age, education level along with the advice and introduction of relatives play an important role, directly influencing the decisions of individuals (Huynh Truong Huy et al., 2020). Besides, the attitude towards insurance and the perception of liability also has a significant impact on the ability of people to save in insurance funds (Do Hoang Anh and associates, 2019).

For private pension plans, two studies by Nguyen Tien Dung et al., (2015) and Truong Thanh Thuy (2016) both inherited Ajzen's TPB model and proved that 3 factors of attitude, subjective norms and perceived behavior control are all statistically significant in the study of the intention to buy pension insurance. In addition, Nguyen Tien Dung et al., (2015) have identified two new factors that also affect people's intention, which are precautionary mentality and level of risk-taking, while Truong Thanh Thuy (2016) has used another factor that is income.

\subsubsection{Research gaps}

Most of the previous studies only looked at the effect of the values that individuals create themselves on their intention to participate in insurance. In fact, many values are created from external parties (insurers) that people gradually inherit to form their own evaluation criteria. Besides, there is not much in-depth and separate research on the intention to participate in pension funds, the intention to buy unemployment insurance of the Vietnamese people. Studies on this topic are not up-to-date compared to current social insurance policies, especially the promulgating of Resolution 28 in 2018 by the Central Executive Commitee. In addition, dimensions measuring brand value have not been used in measuring consumer intention. Since businesses always try to drive the demand for products, people will be affected by marketing campaigns and advertising strategies. This means that their intention will more or less change based on the values that businesses bring.

\section{Methodology}

\subsection{Research model}

The study uses in-depth interview and questionnaire approaches with statistics analysis, empirical framework would be discussed. The below graphic displays briefly how the research process in conducting:

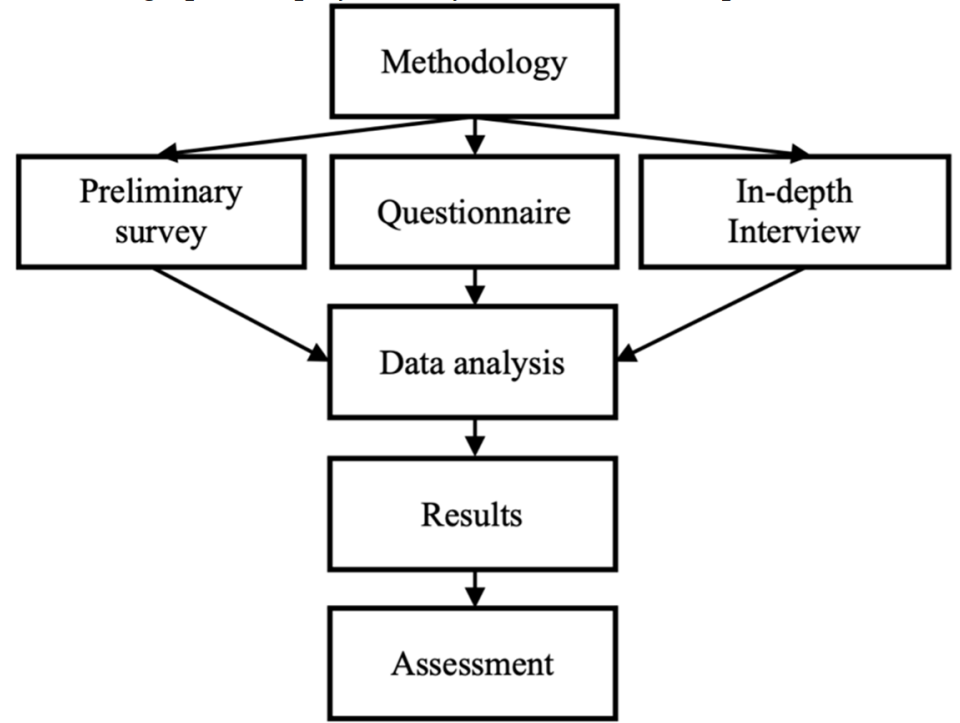

Figure 1. Research framework

According to domestic and foreign research articles, customers' purchase intention will be influenced by many certain factors. For the intention to participate in the private pension in Vietnam, the study inherits the model Theory of reasonable action of Ajzen and Fishbein (1975) The theory of planned behavior (TPB) of Ajzen (1991) 
and goes in-depth to explore the mechanism of the theories. Therefore, the research team identified and linked 5 factors affecting the intention to participate in the private pension in Vietnam.

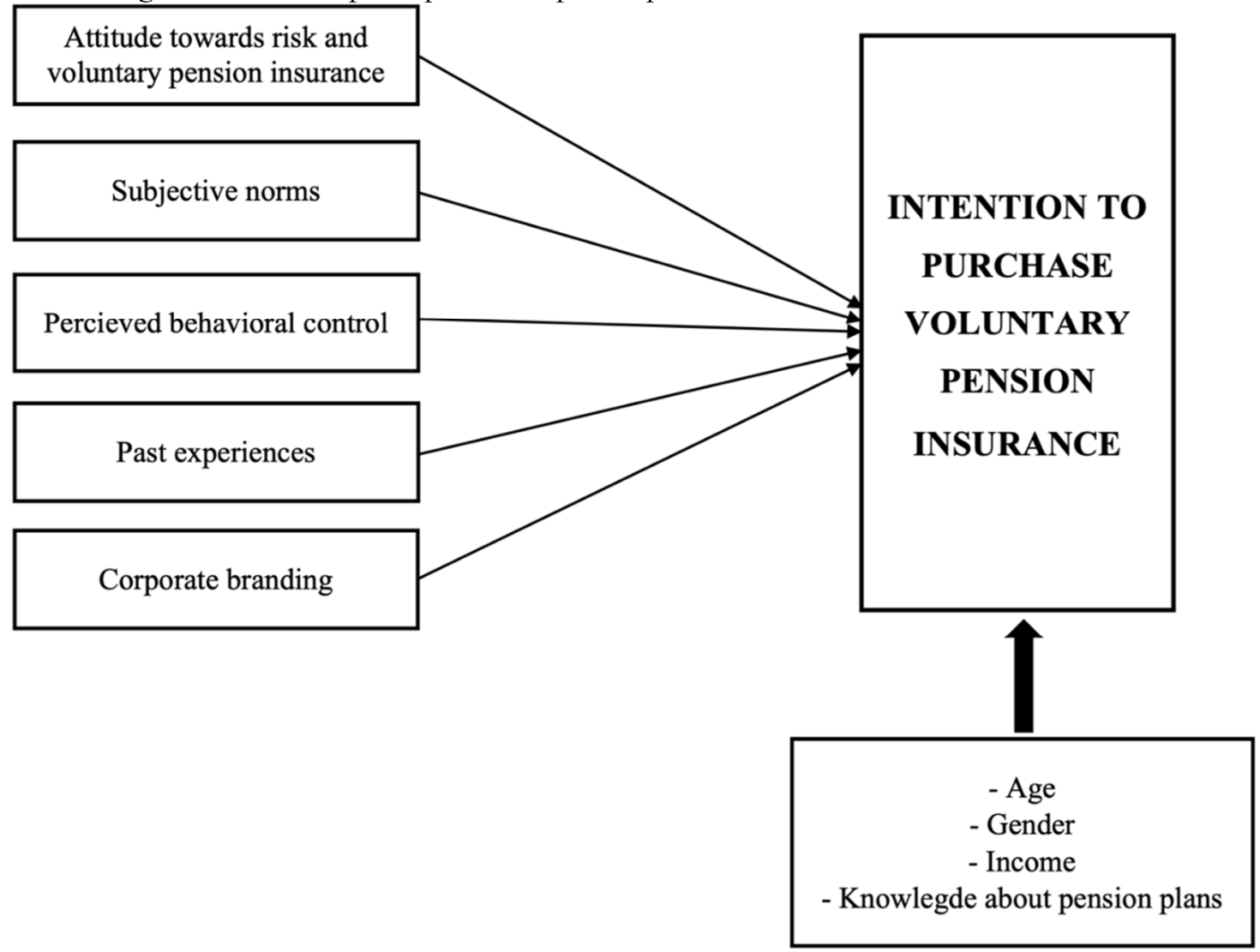

Figure 2. Research model on intention to purchase voluntary pension insurance

\subsection{Interviews and questionnaires}

\subsubsection{Questionnaire}

The questionnaire is designed based on the Likert scale from a scale of 1- "Absolutely disagree" to a 5-point scale - "Totally agree". More than 300 people participated in the survey, including workers over 22 years old with the lowest basic salary of 9 million VND. The study has 5 variables affecting the intention to take part in the private pension, the group has collected 334 eligible votes to supplement the study.

\subsubsection{In-depth interview}

To build accurate survey research, the authors have studied in-depth 5 customers in 4 identified age scales in the survey. Since then, their opinions and behaviors on this insurance product are incorporate with in-depth instructional knowledge of research lecturer.

In-depth interviews were conducted on 5 subjects, 2 people aged 22 to 30, 2 people aged 31 to 40 and 1 person aged 41 to 55 . Those between the age of 31 and 55 see the income factor as a key issue for insurance participation. Besides, they often have a negative view over annuity due to the experience of the past with other life insurance products. On the contrary, 2 young people have a more positive view and want to learn more about this insurance product before intending to participate in pension plans.

\section{Results and Discussion}

Table 1. Summary of factors corresponding to observed variables after factor analysis

\begin{tabular}{|c|c|c|}
\hline Notation & Variables & Factor Name \\
\hline YD & YD1, YD2, YD3 & Intention to purchase voluntary pension insurance \\
\hline TD & TD1, TD2, TD3, TD4, TD6 & Attitude towards risk and pension plans \\
\hline CCQ & CCQ1, CCQ2, CCQ3, CCQ4 & Subjective norms \\
\hline KS & KS1, KS2, KS3, KS4, KS5 & Perceived behavioral control \\
\hline CT & TH1, TH2, TH3, KN2, KN3, KN4 & Past Experiences and Corporate Branding \\
\hline
\end{tabular}

According to the survey results, out of a total of 334 survey samples recovered, the team found that the observations were evenly distributed across five age groups ranging from $30 \%$ to $35 \%$. For income, the group of people with a monthly salary ranging from 9 million VND to 16 million VND accounts for the majority up to 
$50.9 \%$. On the level of understanding, there is not too much difference between the known population $(54.8 \%)$ and the unknown (45.2\%) about the type of voluntary pension insurance.

Table 2. Assessment of level impacts of factors on pension insurance purchase intention

\begin{tabular}{|c|c|c|c|c|c|}
\hline \multicolumn{5}{|c|}{ Descriptive Statistics } \\
\hline & N & Minimum & Maximum & Mean & Std. Deviation \\
\hline TD & 334 & 1.0 & 5.0 & 3.6527 & .86053 \\
\hline CCQ & 334 & 1.0 & 5.0 & 2.8907 & .88914 \\
\hline KS & 334 & 1.0 & 5.0 & 3.4443 & .86059 \\
\hline CT & 334 & 1.0 & 5.0 & 3.4755 & .87536 \\
\hline YD & 334 & 1.0 & 5.0 & 3.0459 & .97614 \\
\hline \multicolumn{7}{|c|}{ Adjusted R Square $=. \mathbf{4 8 7}$} \\
\hline
\end{tabular}

According to Table 2, all variables have a Mean in the range of 2.8 to 3.6. The variable TD (Attitude) has the highest average of 3.6527, showing that the majority of respondents agree with the questions in the Attitude factor. The variable CCQ has the lowest average of 2,8907, showing the average rating for the questions from the respondents. Standard deviation of the lowest variable is KS 0.86053 and highest is variable YD 0.97614.

The result for adjusted R-squared value is 0.487 . This value shows that the independent variables in the regression model explain $48.7 \%$ of the variation in the intention to participate in voluntary pension insurance of the Vietnamese people. The remaining 51.3\% is explained by unobserved variables outside the model or by random error. EFA Analysis requires variables greater than 0.5 , so all variables can be kept. After checking the reliability and validity, all scales were rechecked to ensure the requirements for the next analysis.

\subsection{Correlation Matrix}

Table 3. Analysis of correlation between factors affecting pension insurance purchase intention

\begin{tabular}{|c|c|c|c|c|c|c|}
\hline \multicolumn{7}{|c|}{ Correlations } \\
\hline & & YD & $\mathrm{TD}$ & CCQ & $\mathrm{KS}$ & $\mathrm{CT}$ \\
\hline \multirow{5}{*}{ Pearson Correlation } & YD & 1 & .440 & .627 & .559 & .533 \\
\hline & TD & .440 & 1 & .398 & .492 & .430 \\
\hline & CCQ & .627 & .398 & 1 & .548 & .535 \\
\hline & $\mathrm{KS}$ & .559 & .492 & .548 & 1 & .532 \\
\hline & $\mathrm{CT}$ & .533 & .430 & .535 & .532 & 1 \\
\hline \multirow{5}{*}{ Sig. (2-tailed) } & YD & . & .000 & .000 & .000 & .000 \\
\hline & TD & .000 & . & .000 & .000 & .000 \\
\hline & $\mathrm{CCQ}$ & .000 & .000 & 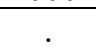 & .000 & .000 \\
\hline & $\mathrm{KS}$ & .000 & .000 & .000 & 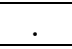 & .000 \\
\hline & $\mathrm{CT}$ & .000 & .000 & .000 & .000 & 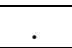 \\
\hline
\end{tabular}

Through the Pearon correlation coefficient, the research team conducted correlation analysis to examine the relationships between quantitative variables. The correlation coefficients in the table show the positive relationship between the relative variables and the level reasonableness. The largest correlation coefficient between the independent variables is 0.548 (correlation between Subjective norms and Percieved behavioral control), the smallest correlation coefficient between the independent variables is 0.398 (correlation between Attitude towards risks and pension plans and Subjective norms). The largest correlation coefficient between the component factors and the dependent variable is 0.627 (correlation between the independent variable Subjective norms and the dependent variable Intention to purchase pension insurance) and the smallest correlation coefficient is 0.440 (correlation relationship between the independent variable Attitude towards risk and pension insurance and the dependent variable Intention to purchase in pension insurance).

Sig value between factors are less than 0.05 , meaning that there exists a linear correlation between the dependent variable and the independent variable. The VIF values of the 4 factors are all less than 2, so there is no multicollinearity phenomenon between the independent variables. The factors used have met the research standard, so they can be used to analyze trends in more depth. 


\subsection{Regression analysis}

\subsubsection{Analysis of the coefficient table}

Table 4. Coefficient of the regression model of determinants of the intention to purchase pension insurance in Vietnam

\begin{tabular}{|c|c|c|c|c|c|c|c|c|}
\hline \multicolumn{9}{|c|}{ Coefficients $^{a}$} \\
\hline \multirow{2}{*}{\multicolumn{2}{|c|}{ Model }} & \multicolumn{2}{|c|}{$\begin{array}{l}\text { Unstandardized } \\
\text { Coefficients }\end{array}$} & \multirow{2}{*}{$\begin{array}{c}\begin{array}{c}\text { Standardized } \\
\text { Coefficients }\end{array} \\
\text { Beta } \\
\end{array}$} & \multirow{2}{*}{$\mathrm{t}$} & \multirow{2}{*}{ Sig. } & \multicolumn{2}{|c|}{ Collinearity Statistics } \\
\hline & & $\mathrm{B}$ & Std. Error & & & & Tolerance & VIF \\
\hline \multirow{5}{*}{1} & (C) & -.094 & .198 & & -.477 & .634 & & \\
\hline & TD & .131 & .053 & .115 & 2.478 & .014 & .710 & 1.408 \\
\hline & $\mathrm{CCQ}$ & .413 & .055 & .376 & 7.473 & .000 & .609 & 1.641 \\
\hline & $\mathrm{KS}$ & .232 & .059 & .204 & 3.918 & .000 & .567 & 1.763 \\
\hline & CT & .193 & .056 & .173 & 3.447 & .001 & .612 & 1.635 \\
\hline
\end{tabular}

In the table 4 , Sig value. corresponding to 4 determinants in the regression model is $<0.05$, proving that these factors are statistically significant. The variation of all 4 recognized determinant can explain the variation of the dependent variable Intention to participate in the private pension and the degree of variation is expressed by the corresponding standardized coefficient $b$ for each group. Thus, the multivariate regression model for the 334 subjects study sample would be following:

$$
\mathrm{YD}=\text { 0.115. TD + 0.376.CCQ + 0.204. KS + 0.173. CT }
$$

Based on the results model, all factors have a positive effect on the respondents' intention to participate in private pension. In which, Subjective Norms factor has the highest influence with normalized regression coefficient $b=0.376$. This means that, if the other factors are kept fixed, each additional unit in the Subjective Norms of the private pension of people will increase their purchase intention by 0.376 units. Similarly, the remaining factors will also contribute to the corresponding influence level as TD is $0.115, \mathrm{KS}$ is 0.204 and $\mathrm{CT}$ is 0.173. The Attitude factor, according to quantitative results, has the least influence on the dependent variable.

The VIF values of the 4 factors is less than 2, so there is no multicollinearity phenomenon between the independent variables. The factors used have met the research targets, so they can be used for further analysis.

\subsubsection{Attitude toward risks and pension insurance}

Table 5. Descriptive statistics of Attitude toward risks and pension insurance

\begin{tabular}{|c|c|c|c|c|c|}
\hline \multicolumn{5}{|c|}{ Descriptive Statistics } \\
\hline & $\mathbf{N}$ & Minimum & Maximum & Mean & Std. Deviation \\
\hline TD1 & 334 & 1.0 & 5.0 & 3.503 & 1.0562 \\
\hline TD2 & 334 & 1.0 & 5.0 & 3.536 & 1.0528 \\
\hline TD3 & 334 & 1.0 & 5.0 & 3.844 & .9740 \\
\hline TD4 & 334 & 1.0 & 5.0 & 3.796 & .9713 \\
\hline TD5 & 334 & 1.0 & 5.0 & 3.003 & 1.0296 \\
\hline TD6 & 334 & 1.0 & 5.0 & 3.584 & 1.0181 \\
\hline
\end{tabular}

From the table 5, Attitude towards risks and the private pension are the factors that have the least impact on survey participants, including several reasons. Firstly, the private pension is a relatively new type of insurance and is still unfamiliar to the majority of Vietnamese customers. Secondly, the number of contracts, the contract value, and the number of companies issuing voluntary pension insurance on the market are modest compared to other life insurance products. Therefore, we can see that the coverage of the private pension is limited as well as not enough of certain circulating value in the market, leading to an inconsistent attitude with this type of insurance. In general, the participants were neutral or inclined to agree with the observation of the observed variable.

The client's assessment of the group of observed variables Attitude to risks and the private pension is quite equal and fluctuates at an average level from 3,003 to 3,844, that is, they have no opinion and are inclined to agree. In which, the observed variable TD5 (Willingness to accept the risk of loss when investing) has the lowest rating $(3,003)$. Respondents who do not take a stance on their taking risks when entering an investment show that they perceive the need for assurance when entering an investment and do not expect the worst scenario to happen. The observed variable TD3 (Concern about health risks) received the highest consensus $(3,844)$. This shows that Vietnamese people in general and the number of people surveyed in particular consider that health is the top concern. Health is the most important aspects for people to ensure their ability to work and is also one of the main factors for them to consider when participating in types of insurance to help prevent risks. 


\subsubsection{Subjective norms}

Table 6. Descriptive statistics of Subjective norms

\begin{tabular}{|l|c|c|c|c|c|}
\hline \multicolumn{5}{|c|}{ Descriptive Statistics } \\
\hline & $\mathbf{N}$ & Minimum & Maximum & Mean & Std. Deviation \\
\hline CCQ1 & 334 & 1.0 & 5.0 & 2.877 & .9894 \\
\hline CCQ2 & 334 & 1.0 & 5.0 & 2.931 & 1.0360 \\
\hline CCQ3 & 334 & 1.0 & 5.0 & 2.728 & .9867 \\
\hline CCQ4 & 334 & 1.0 & 5.0 & 3.027 & 1.0234 \\
\hline
\end{tabular}

Half of the total sample collected is unknown about the private pension insurance products. Because this type of pension insurance is still quite new, the surveyees do not have certain knowledge about it, so they tend to disagree with the research team's judgment regarding Subjective Norms determinant. The mean value of observed variables fluctuated insignificantly between 2,728 and 3,027, meaning that they disagree or disagree. Specifically, CCQ3 (All acquaintances have participate in pension plans) is the lowest rated $(2,728)$ and CCQ4 (The information sources remind me of the necessary private pension) has the highest index $(3,027)$. Currently, only 6 out of 18 businesses are licensed to operate the pension insurance, so the coverage of this product is low, not popular among many households and friends. That is why the CCQ3 survey variable received the lowest rating. Similarly, the variable CCQ4 is assessed at the level of medial due to the lack of advertising on mass media sources as well as the level of brand's awareness among customers is not significant.

\subsubsection{Perceived behavioral control}

Table 7. Descriptive statistics of Perceived behavioral control

\begin{tabular}{|l|c|c|c|c|c|}
\hline \multicolumn{5}{|c|}{ Descriptive Statistics } \\
\hline & N & Minimum & Maximum & Mean & Std. Deviation \\
\hline KS1 & 334 & 1.0 & 5.0 & 3.249 & 1.0199 \\
\hline KS2 & 334 & 1.0 & 5.0 & 3.278 & .9972 \\
\hline KS3 & 334 & 1.0 & 5.0 & 3.599 & 1.0108 \\
\hline KS4 & 334 & 1.0 & 5.0 & 3.491 & 1.0390 \\
\hline KS5 & 334 & 1.0 & 5.0 & 3.605 & 1.1202 \\
\hline
\end{tabular}

In this group of factors, survey respondents tended to agree with the observations of the observed variable, the average result from 3,249 to 3,605. In which, the variable KS1 (Having enough finance to participate in the private pension) is lowest rated at 3,249, and KS5 (Having searched for information before joining) is rated the highest with 3,605. From the results of the survey sample, 169/334 (equivalent to 50.6\%) of the respondents have an income between VND 9 million and VND 16 million. Most survey participants own income in the range of tax exemption and tax reduction. Moreover, survey participants are in the age group 31-55 (accounting for more than $70 \%$ ), which they are at married age and having children, and they are being responsible for taking care of elderly parents, so the salary of VND 9-16 million/month is considered quite modest and not enough to pay for the voluntary insurance package. According to Maslow's needs pyramid, safety needs are only born after their survival needs are fully met. Therefore, the respondents tended to give a neutral opinion about having financial conditions to participate. In contrast, the variable KS5 received a relatively high rating of 3,605 indicating that most of the participants agreed that learning about this new type of insurance is necessary before investing in this product category.

\subsubsection{Past experiences}

Table 8. Descriptive statistics of Past experiences

\begin{tabular}{|l|c|c|c|c|c|}
\hline \multicolumn{5}{|c|}{ Descriptive Statistics } \\
\hline & N & Minimum & Maximum & Mean & Std. Deviation \\
\hline KN1 & 334 & 1.0 & 5.0 & 3.105 & 1.0923 \\
\hline KN2 & 334 & 1.0 & 5.0 & 3.156 & 1.1041 \\
\hline KN3 & 334 & 1.0 & 5.0 & 3.240 & 1.0861 \\
\hline KN4 & 334 & 1.0 & 5.0 & 3.419 & 1.0896 \\
\hline
\end{tabular}

Based on the observed sample, the group easily found that the observed variables of this factor were only in agreement with the statement (from 3.105 to 4.419). In other words, the factors of experience in the past had a small impact on the intention to participate in UI. Specifically, the observed variable 'Products meet demand' (KN1) is at the lowest level and the variable 'Easy to buy insurance' (KN4) has the highest rating. The majority of beneficiaries and beneficiaries of pension insurance are elderly, retired and in poor health. However, the respondents are mainly aged 31-55, they are still in working age, in good health, and not covered by the package. Therefore, when making comments on the issue of whether life insurance can meet the needs, the participants expressed neutral opinions, tending to agree. In addition, the group agreed with the statement that 'Buying this insurance is easy' because currently the life insurance market in Vietnam has 18 businesses and a large number of sales staff. Diverse policy values make joining life insurance much more convenient. 


\subsubsection{Corporate branding}

Table 9. Descriptive statistics of Corporate branding

\begin{tabular}{|c|c|c|c|c|c|}
\hline \multicolumn{5}{|c|}{ Descriptive Statistics } \\
\hline & N & Minimum & Maximum & Mean & Std. Deviation \\
\hline TH1 & 334 & 1.0 & 5.0 & 3.796 & 1.0656 \\
\hline TH2 & 334 & 1.0 & 5.0 & 3.653 & 1.0537 \\
\hline TH3 & 334 & 1.0 & 5.0 & 3.590 & 1.0495 \\
\hline
\end{tabular}

According to the results of analyzing the data of the research team, the evaluation level of this factor is in the range from 3,590 to 3,796 with the difference between observed variables is negligible. In which, 'Companies that do good communication that can build customer trust' (TH3) have the lowest rating of 3,590 and 'Corporate reputation is an important factor when buying retirement insurance.' (TH1) reached the highest consensus level of 3,796. This shows that people in general and survey participants in particular show interest in the brand of the insurance company before making a decision to join pension funds. Customers have a mindset of risk prevention, so they often learn carefully about the businesses that currently offer voluntary pension insurance in the market such as their financial situation, product information and reviews of other users to compare and give. out the right choice. In terms of good media observation variable. In addition, the data also shows that although it is undeniable that the good communication of insurance companies will be easier to reach customers, on the other hand, if misused, the communication is also susceptible to backfire used because people no longer believe PR or polish words.

\section{Recommendations}

\subsection{Recommendations for insurance enterprises}

According to the study, the annuity market is a market with strong potential for growth in the future. Therefore, insurance businesses need to urgently catch up with the trend and create its own competitive advantages in the market. The research team suggest some of the research team's recommendations for insurance companies following:

First, businesses should highlight the outstanding features and value of the private pension to disseminate it to buyers. Specifically, it is important to focus on the main benefit of insurance, which is the protection and prevention of risks by diversifying the financial portfolio, benefits, and medical facilities are included in the insurance package to attract customers when health is one of the issues of concern according to the study.

Second, businesses also need to pay attention to marketing information as it is the bridge leading customers to the business and product packages. Enterprises need to clearly define the customer segment to perform the communication campangn in the best possible way.

Third, enterprises should focus on training to improve the professionalism of its staff members. Specially, firms should pay attention to business ethics, prestige, and trust problems. The business needs to be aware of the importance of reputation and business ethics toward revenue and propagate it to the employees. In particular, businesses need to ensure transparency in business as well as constantly publish their financial and operating reports with actual survey data for ease of reference.

Fourth, businesses always need to improve customer care services. They should regularly listen to suggestions and recommendations from customers about the quality of services. Provided the feedbacks, businesses will know what customers are facing and fix promptly to prevent service gaps, partly improve the reputation of businesses and users' view on annuity.

Fifth, companies should design product packages that are easy to understand, clear, and unambiguous to make products easier for users to comprehend.

\subsection{Recommendations to the State of Vietnam}

The voluntary pension insurance is a new form insurance and is in the early stages of implementation, so the State's intervention is needed in the development of laws and circulars guiding its implementation. In general, the research team gives the following recommendations to the State as follows:

First, the State needs to promulgate detailed guidance on the implementation of the contract, the legal regulations, and frameworks that regulate the rights, responsibilities, and obligations of both contracting parties.

Second, the State could assigns the Ministry of Finance and relevant agencies to participate in the management and supervision of enterprises' business activities, avoiding unfair competition and non-transparent business practices. The law should seriously handle businesses with false communications, or even fraudulent misappropriation of customers' property.

Third, the State should enact policies to promote and improve the professional quality and ethics of insurance enterprises towards their customers. Relevant ministries and agencies should give the criteria for evaluating and classifying enterprises as a basis for reference.

Fourth, the State needs to propagate and raise people's awareness about life insurance in general and the 
pension plans in particular. This will not only brings benefits to individuals but also to the community and society due to increased capital.

\section{Conclusion and limitations}

Through the process of researching and discussing the results, the team identified a research model with 5 factors affecting the intention to buy unemployment insurance in Vietnam: Attitude to risk and pension insurance, Subjective norms, Percieved behavioral control, Past experiences, and Corporate branding. The final result is that all of the above factors have a positive effect on the people's intention to participate.

Subjective norms factor has the greatest influence on the intention to buy voluntary pension insurance. Indeed, Vietnam is considered to be a collective culture, so the psychology of Vietnamese consumers is easily influenced by the "herd mentality". They often go through the observation of the behavior of people. People around to learn and feel more secure when someone has used it, so the tendency to apply for insurance will be influenced by others.

Among the factors affecting the intention to participate in voluntary pension insurance, Attitude towards risk and pension plan are the factors that have the least impact on respondents. Voluntary pension insurance is a relatively new type of insurance and is still unfamiliar to the majority of customers in Vietnam. The number of policies to support the demand for pension insurance and number of companies issuing voluntary retirement insurance on the market are much lower compared to other life insurance products. It is therefore difficult to give a clear attitude towards this type of insurance. This ambiguity is shown in the statistical analysis of the attitude factor. In general, the participants were neutral or inclined to agree with the observation of the observed variable.

Based on the quantitative findings, the solutions to improve and enhance the positive influence of factors on the intention to participate in unemployment insurance in Vietnam are proposed to emphasize that insurers need to diversify products and distribution channels, improve the quality of services especially after-sales service, while applying software technology to the professional stages in insurance and providing applications to help customers more easily access information sources. Firms can also simplify procedures based on standard procedures, train highly qualified insurance staff with good attitude. In addition, the State can contribute to propagating, promoting demand as well as supporting supply for potential insurance companies with enough resources to participate in this market.

However, the topic still has certain limitations: Firstly, the survey form is too small to evaluate the intention of the whole country. Secondly, the lack of comments from experts in the insurance sector also affects the process of building a suitable model. From this limitation, the team hopes to be further researched on a wider scale in order to get comprehensive research, which is the basis for the promulgation of policies and as well as based on the strategies of life smes for unemployment insurance products.

\section{References}

Amin, H. (2012), 'An Analysis on Islamic Insurance Participation', Journal of Management, 34(2012), 11-20.

Ajzen, I. (1991), 'The theory of Planed Behavior', Organizational behavior and human processes, 50(2), 179-211.

Ajzen, I., \& Fishbein, M. (1980), Understanding attitudes and predicting social behavior, Englewood-Cliffs, NJ Prentice-Hall.

Chien, C., I-Han \& Chen (2014), 'A Study of the Effect of Experiential Marketing on Customer Purchase Intention: Case Study of the Taipei International Sports Cycle Show', The Sport Journal, 22.

Do Hoang Anh and Pham Hong Manh (2019), 'Factors affecting people's decisions to participate in life insurance in the city. Quang Ngai', Finance Magazine, last accessed 10 April 2021, from, $<$ https://tapchitaichinh.vn/nghien-cuu-trao-doi/nhan-to-anh-huong-den-quyet-dinh-tham-gia-bao-hiemnhan-tho-cua-nguoi-dan-tai-tp-quang-ngai-302400.html $>$

Fishbein, M. (1967), Attitude and the Prediction of Behavior, In Morris Fishbein (ed.), Readings in Attitudes Theory and Measurement, Wiley, New York.

Fishbein, M., \& Ajzen, I. (1975), Belief, attitude, intention and behaviour: An introduction to theory and research, Reading, MA: Addison-Wesley, USA.

Hassan, K.H., Rahim, R.A., Ahmad, F., Zainuddin, Merican, R.R. \& Bahari, S.K. (2016), 'Retirement Planning Behaviour of Working Individuals and Legal Proposition for New Pension System in Malaysia', Journal of Politics and Law, 9(4), 43.

Heenkenda, S. (2016), 'Determinants of Dropouts from Voluntary Pension Scheme: Evidence from Sri Lanka', International Journal of Business and Management Society, 1(1), 10-22.

Hong, G.S., Sung,J. \& Kim, S.M. (2002), 'Saving Behaviour Among Korean Households', Family and Consumer Sciences Research Journal, 30(4), 437-462.

Huynh Truong Huy, Nguyen Thi Kim Dung, Nguyen Mai Uyen and Nguyen Thanh Liem (2020), 'Insurance policy analysis retirement life in Can Tho City', Journal of Commercial Science, 145 (19), 36-46.

Jahan, T. \& Sabbir, M.M. (2018), 'Analysis of consumer purchase intention of life insurance: Bangladesh perspective', Business Review - A Journal of Business Administration Discipline, 13(2), 13-28. 
Khan, I. \& Rahman, Z. (2015), 'Influence of Experiental Marketing on Customer Purchase Intention: A Study of Passenger Car Market', Management and Labour Studies, 39(3), 319-328.

Lavidge, R. \& Steiner, G. (1961), 'A Model of Predictive Measurements of Advertising Effectiveness', Journal of Marketing, 25, 59-62.

Letamendia, L.N. \& Silva, A.C. (2015), 'Factors influencing saving and investment: Financial literacy, attitudes and trust', Center for Insurance Study, 140(10).

Lusardi, A. \& Tufano, P. (2009), 'Debt, Literacy, Financial Experiences, and Overindebtedness', NBER, 14808, DOI: $10.3386 / \mathrm{w} 14808$

Mahdzan, N.S. \& Victorian, S.M.P. (2013), 'The determinants of life insurance demand: A focus on saving motives and financial literacy', Asian Social Science, 9(5), 274- 284.

Maison, D., Marchlewska, M., Sekscinska, K., Wojciechowska, J.D. \& Lozowski, F. (2019), 'You don’t have to be rich to save money: On the relationship between objective versus subjective financial situation and having savings', PloS One, 14(4), DOI: 10.1371/journal.pone.0214396.

Nguyen Tien Dung, Pham Ngoc Tram Anh and Pham Tien Minh (2015), 'Factors affecting the intention to buy voluntary pension insurance of Ho Chi Minh City residents', Science and Technology Development Journal, 18 (Q4- 2015), 45-54.

Outcault, S. (2012), Saving for the Future: Trends, Patterns and Decision-Making Processes Among Young American, RAND Corporation, US.

Schmitt, B.H. (1999), 'Experiential Marketing', Journal of Marketing Management, 15(1-3), 53-67.

Truong Thanh Thuy (2016), 'Factors affecting the intention to buy voluntary pension insurance for individual customers in Binh Long town, Binh Phuoc province', master's thesis, Ho Chi Minh City University of Technology.

Wei, S.J. \& Zhang, X. (2011), 'The Competitive Saving Motive: Evidence from Rising Sex Ratios and Savings Rates in China', Journal of Political Economy, 119(3), 511-564.

Yusof, R., Sabri, M.F., Rahim, H.A. \& Zuroni, M. (2018), 'Examining the behavioural intention to save in a voluntary retirement fund in Malaysia', Malaysian Journal of Consumer and Family Economics, 21, 78-102.

Zakaria, Z., Azmi, N.M., Hassan, N.F.H.N., Salleh, W.A., Tajuddin, M.T.H.M., Sallem, N.R. M., \& Noor, J.M.M. (2016), 'The intention to purchase life insurance: A case study of staff in public universities', Procedia Economics and Finance, 37(16), 358-365.

12th Central Committee of the Communist Party of Vietnam (2018), Resolution No. 28 on reform of social insurance policy, issued on 23 May 2018. 